\title{
The role of green technology to investigate green supply chain management practice and firm performance
}

\author{
Zeni Rusmawati $^{\mathrm{a}}$ and Noorlailie Soewarno ${ }^{\mathrm{b}^{*}}$
}

${ }^{a}$ PhD Student of Airlangga University; Department of Accounting, Muhammadiyah University of Surabaya ${ }^{b}$ Department of Accounting, Airlangga University, Indonesia

\begin{tabular}{l}
\hline C H R O N I C L E \\
\hline Article history: \\
Received October 28, 2020 \\
Received in revised format \\
January, 15, 2021 \\
Accepted February 42021 \\
Available online \\
February 42021 \\
\hline Keywords: \\
GSCM Practice \\
Environmental performance \\
Green economic performance \\
Green Technology
\end{tabular}

A B S T R A C T
This study examined the relationship between green supply chain management (GSCM) on the environment and green economic performance with the moderator prediction context, which is a very fundamental approach for developing stronger theories. The writers chose green technology as a unique moderator in the context of GSCM practices and performance. The purpose of this study is to determine the role of moderating effects of green technology in investigating the relationship between green supply chain management (GSCM) practices and firm performance (environmental and green economic performance). By employing survey methodology using a purposive sampling technique, the data collected from 96 respondents in various manufacturing firms. The hypotheses were tested through SEM-PLS using SmartPLS. The further results show that the results of hypothesis testing indicate that GSCM practices (GSCM) have a positive and significant effect on environmental performance (EP) and green economic performance (GEP). The study also found that the role of green technology as a moderating variable can strengthen the positive relationship between GSCM Practices and environmental performance. While the moderation effect of Green technology (GT) can weaken the positive relationship between GSCM Practices and green economic performance (GEP).

\section{Introduction}

Environmental issues have become a concern in the industrial world. To be able to compete, the industry must be able to expand at the level of production and consumption to improve supply chain management (SCM) (Zhu, Geng, \& Sarkis, 2013; Zhu \& Sarkis, 2007). In carrying out the expansion, the company activities generate pollutants, including gas/smoke emission from transportation (shipping and supplying supplies) as well as from production process activities. Also, each industry produces waste from production and labor activities(Bhattacharya et al., 2014) and these impacts must be considered by management (Laosirihongthong et al., 2013; Pono \& Munizu, 2021), which ultimately refers to the basics of the Green Supply Chain Management approach (GSCM). GSCM has emerged as a potential solution that seeks to respond to environmental issues raised by industry developments. GSCM accepted as a relatively new concept with limited structured literature (Holt \& Ghobadian, 2009). From a business standpoint, a study shows that the environmental consequences of a logistics system are also a major part of customer service because customers increasingly demand environmentally friendly products and services. Another study explains that GSCM practices go further, combining environmental management practices with traditional SCM concepts (Kumar et al, 2015). Some researchers concluded that the practice of green supply chain management is a strategic choice of business organizations because of its potential in creating value (Li et al., 2006; Gimenez \& Ventura, 2005; Watanabe, 2001). Meanwhile, Frohlich and Westbrook (2012) concluded that integrated supply chain practices would improve operational performance, delivery time, and transaction

* Corresponding author

E-mail address: noorlailie-s@feb.unair.ac.id (N. Soewarno)

C 2021 by the authors; licensee Growing Science.

doi: $10.5267 /$ j.uscm.2021.2.001 
cost efficiency. This view is also supported by Gonzalez-Benito (2017), who concluded that GSCM practices affect operational performance from a purchasing perspective. A similar phenomenon also occurs in Indonesia. However, not all GSCM practice guidelines are successful (Kim, 2006). In Indonesia, for example, failures in GSCM practices are caused by weak collaboration.

A number of literatures show that the application of GSCM practices has a positive effect on environmental performance (Cousins et al., 2019) and economic performance (Jaaron et al., 2018). Another study shows that managers face significant challenges in adopting GSCM practices (Kirchoff et al., 2016), there are obstacles in implementing them. In this context, our research seeks to identify why performance outcomes are uncertain across various implementations of GSCM practices and is directly motivated by calls for research exploring broader moderating effects on GSCM implementation and performance (Cousins et al., 2019). The differences in previous research have increased the need to test the consistency of the application of GSCM practices in different contexts. Recently, what has caught public attention is a form of business awareness on environmental issues through the adoption of GSCM with business innovation (Rao, 2007). The focus of this research is to examine the relationship between GSCM on the environment and green economic performance with the context of moderator prediction, which is a pivotal approach to develop stronger theories. The writers chose green technology as a unique moderator in the context of GSCM practices and performance. The technology is the main instrument in achieving specific results from environmental innovation (Horbach et al., 2008). A business needs technology to do environmentally friendly production, consumers need high-quality products at affordable prices, and people need a safe environment without pollution for future generations (Fernando et al., 2016). However, the initial investment in technology is quite large, and it also requires a period for producers to get a return (Allan et al., 2013). The development and use of such technology can be a problem for companies because using green technology requires expensive costs and requires massive investment. Thus, debates about costs and benefits in adopting green technology and infrastructure are used to support eco-innovation and business results (Knobloch \& Mercure, 2016; Allan et al., 2013).

This study aims to offer a new perspective on green technology as a moderation of the influence of GSCM Practice with Performance (environment and green economy) on the manufacturing industry in East Java Province, Indonesia. Furthermore, the writers intend to achieve a better understanding of strategies and policies designed to meet the challenges that arise in terms of sustainable economic and environmental development. The industrial sector in Indonesia can realize development (Wikaningrum \& Hakiki, 2020). Based on the Ministry of Industry's records, throughout 2019, the manufacturing industry was able to make a significant contribution to the achievement of the national investment value of Rp216 trillion or contributed $26.7 \%$ of the total investment realization in Indonesia last year.

\section{Theoretical Background}

The Natural Resource-Based View (NRBV) is a development of the Resource-Based View (RBV) theory that has been developed previously. RBV provides a theoretical framework to explain how companies can mobilize company-owned resources to achieve sustainable competitive advantage (Barney, 1986). The company must not only consider the available resources but also how these resources will fit into the external environment of the company in this case it is natural (Hart \& Dowell, 2011). It can link internal and external resources in RBV theory and thus propose NRBV to better understand the fit between an organization and its natural environment (Gavronski et al., 2011). In particular, NRBV highlights that sustainability is a resource that competitors cannot easily copy or acquire due to institutional or capacity constraints. Therefore, the natural environment is a "strategic resource" from an RBV perspective (Hart \& Dowell, 2011; Gavronski et al., 2011). NRBV focuses on the natural environment, the company is not only limited by internal resources, but also by the availability and cost of external resources(Cousins et al., 2019). Three interrelated environmental strategies proposed by the NRBV: "pollution prevention" (minimizing damage and environmental degradation such as reducing emissions, reducing packaging and so on), "product stewardship" (minimizing product life cycle costs through, for example, product modification or redesign).

\section{Hypothesis}

\subsection{GSCM practices and firm performance}

GSCM is the strategic integration, achievement of the corporate social environment, and systematic coordination of business processes between key organizations to improve the long-term economic performance of individual companies and their supply chains (Zhu et al., 2012; Cousins et al., 2019). The authors focus their attention on GSCM practices in particular, which include organizational strategies such as internal environmental management, a friendly purchasing environment, supplier selection, and investment recovery (Jaaron et al., 2018). The aim of this study is to examine the possibilities that influence the relationship between GSCM practice and firm performance. Nonetheless, the writers present the GSCM to practice linking environmental and green economic performance as a basic hypothesis for statistical testing and further empirical support of this important relationship. (Cousins et al., 2019). This hypothesis is based on the NRBV theory, which has a focus on achieving competitive advantage associated with the natural environment of an organization (BalsandTate, 2018 ) by focusing on developing resources to achieve environmental goals. The NRBV theory also indicates that GSCM 
practices lead to improved environmental performance (Cousins et al., 2019). In other research, GSCM practices are also associated with costs (economic performance) (Cousins et al., 2019) such as waste management, use of cheaper recycled raw materials, efficient energy consumption, minimization of environmental accidents, and several components. in products and pollution. prevention, which limits the costs of compliance with environmental regulations and green operational costs (green economy performance) (Çankaya \& Sezen, 2019; Mehdikhani \& Valmohammadi, 2019)

\section{$\mathrm{H}_{1}$. GSCM practices are positively associated with environmental performance.}

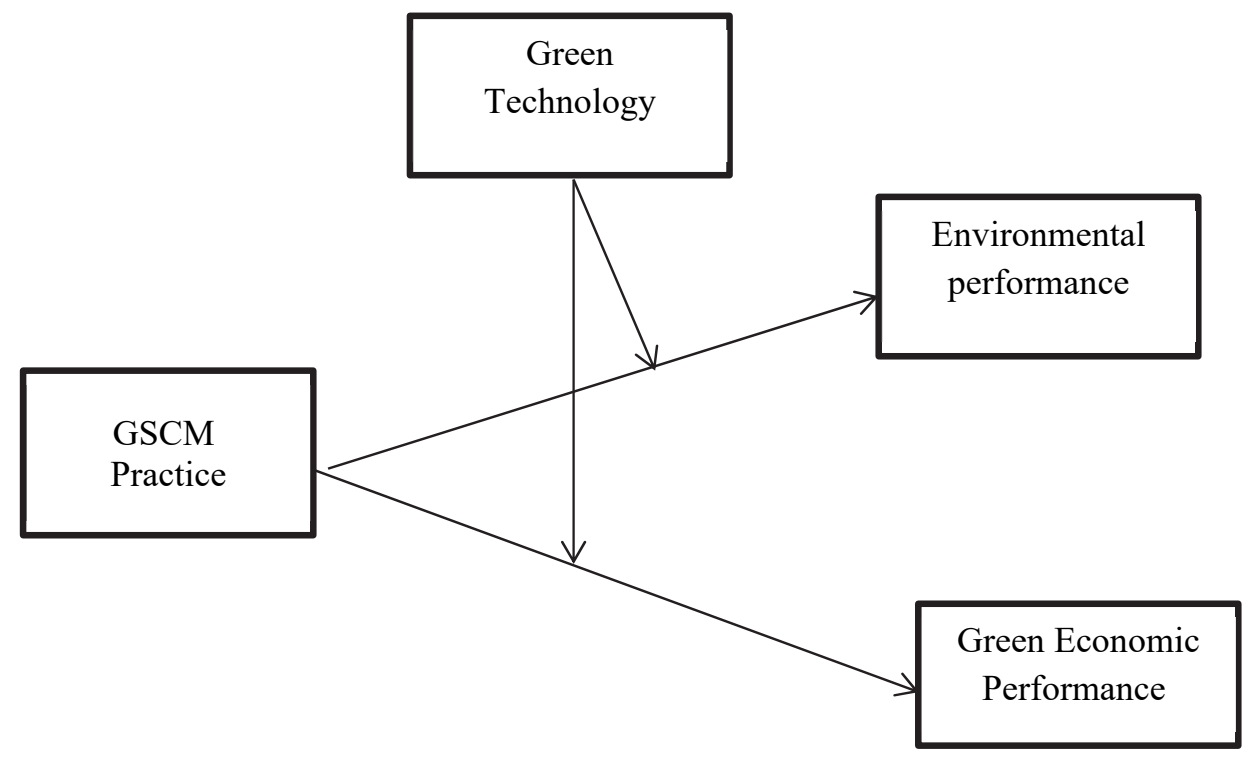

Fig. 1. Conceptual Framework

Regarding the relationship between the supply chain and the external environment, (Susanty et al., 2019) stated that supplier collaboration has a positive effect on economic performance because relationships between organizations and between companies in the supply chain can help build trust and reduce risk. In addition, another reason that explains the positive relationship between GSCM practices and green economy performance is the effect of winning environmental awards by companies so as to increase their share prices (Klassen \& McLaughlin, 1996). In particular, Klassen and McLaughlin (1996) show that the ecological behavior of companies is valued by the stock market, which rewards them with a higher share price (Heinkel et al., 2015; Ba et al., 2013). Thus, a hypothesis related to the green economy outcome of GSCM can be made as follows.

\section{$\mathrm{H}_{2}$. GSCM practices are positively associated with operating green economic performance.}

\subsection{The Moderating Role of Green Technology}

Green Technology is a form of technology diffusion that is very important for global economic and environmental development. However, the initial investment in technology is quite large, and it also requires a period for producers to get a return (Chan et al., 2912). The development and use of such technology can be a problem for companies because using green technology requires expensive costs and massive investment. Thus, debates about costs and benefits in adopting green technology and infrastructure, are used to support eco-innovation and business results (Kemp \& Oltra, 2011; Rennings \& Rammer, 2011; Doran \& Ryan, 2014; Allan et al., 2014; Knobloch \& Mercure, 2016). Cost, benefits, technical expertise, and resources determine whether these benefits can be justified or not from an economic perspective (Larson and Gray, 2011). Empirical research in project management (Larson \& Gray, 2011) shows that individuals cannot calculate all the costs and benefits when making decisions. Studies based on engineering data regularly report that green investments that appear to be cost-effective do not occur (Knobloch \& Mercure, 2016). The reduction of environmental waste at negative costs is consistently found in the literature (Allan et al., 2014). McKinsey and Company (2009) claim that global CO2 emissions can be reduced by $11 \mathrm{Gt}$ per year by investing in cost-effective and environmentally friendly technologies, which is not the case today.

$\mathrm{H}_{3}$. The relationship between GSCM practices and environmental performance is stronger when a firm has green technology.

$\mathrm{H}_{4}$. The relationship between GSCM practices and environmental performance is weaker when a firm has green technology. 


\section{Research Method}

The current study adopted a quantitative research approach that provides advantages in producing changes in natural populations through the population and the use of statistical techniques (Kelle, 2006). The survey methodology was adopted in the form of a self-administered questionnaire to collect data from respondents.

\subsection{Sample}

The Central Bureau of Statistics for East Java Province in 2018 recorded 334 large and small industrial companies in East Java Province. However, there are only 160 companies that have implemented green business. The writers carried out random sampling to determine the sample of this study.

\subsection{Data Analysis}

The quantitative approach is based on questionnaires, limited to statistical numbers, measurement, and many forms of statistical tool analysis (Chatchawanchanchanakij et al., 2019). The quantitative research design has become the framework for this study, assisting researchers to examine the sample of respondents thoroughly; opinions about the proposed phenomenon. In this case, study to determine the role of green technology variables in identifying the relationship GSCM practices with environmental performance and green economic performance researchers used questionnaires as the main tool. The questionnaire was used to analyze the relationship between variables designed according to the objectives, problems, and research hypotheses. Data collected through surveys were inputted into Smart-PLS and then analyzed.

\subsection{Measurement}

For data collection, a self-administered questionnaire was developed. It was divided into two parts: the first part consisted of measuring items adapted from previous research work, and the second part consisted of questions related to the demographic details of respondents. Details of the measurement items were summarized in Table I. This study has four variables, namely GMCM practices (eco-design, supply chain partnerships, and internal environmental management), environmental performance (waste recycling, reducing waste, product recycling and reducing the use of hazardous materials), green economic performance (reduction of costs and resource management efficiency), and green technology (cost and benefit, payback period, company capability). All measurement items are on a six-point Likert scale (Causins, et, al., 2019), starting from 1: Strongly Disagree to 6: Strongly Agree.

\section{Data analysis and results}

A purposive sampling technique was used for data collection. Respondents were confident in data protection. In the first quarter of 2020, around 160 questionnaires were distributed to manufacturing companies in East Java Province-Indonesia. After the screening, the final sample size of this study was 96 respondents, with a response rate of 60 percent. The current study sample size meets the minimum sample size threshold, based on the rule method (recommended: 10 times the number of variables) (Hair et al., 2011). To calculate general method biases, the procedure guidelines, discussed by MacKenzie and Podsakoff (2012), were followed, especially at the stage of designing a questionnaire and giving it to respondents. Because of the non-response bias, late respondents are considered as non-responders according to their behavior (Saeed et al., 2018).

Table 1

Detail of measures

\begin{tabular}{lll}
\hline \multicolumn{1}{c}{ Variable } & No. of items & \multicolumn{1}{c}{ Source } \\
\hline Green Supply Chain Management Practice (GSCM) & 7 & Zhu and Sarkis 2004; Zhu et al. 2008; Causins et al, 2019. \\
Environmental performance (EP) & 9 & Zhu et al. 2013; Causins et al, 2019 \\
Green Economic Performance (GEP) & 4 & Cankaya, et al, 2019; Mehdikhani \& Valmohammadi, 2019 \\
Green Technology (GT) & 10 & Allan, et al., 2014; Kong, et. Al 2016 \\
\hline
\end{tabular}

SEM-PLS is currently one of the powerful techniques for analyzing data about social problems (Chatchawanchanchanakij et al., 2019). SEM-PLS is a two-step equation, which is an advanced form of multiple regression. It contributes to two assessments: the assessment of the inner model and the evaluation of the outer model (Patidar \& Din, 2018).

Before testing a hypothesis, a reliability and data validity test must be performed first. Indicators of each variable are declared valid and significant if they have a loading factor, Average Variance Extracted (AVE), composite reliability with consecutively the value of more than 0.5 (Hair et al., 2017). Table 2 shows that all the indicators comply with the requirements above. In the table, the results of composite reliability (RC) satisfactory is above 0.7 , hence it can be concluded that the entire block of items is indeed a measure of their respective constructs. This means that this study has passed the reliability and data validity test. So, the next test can be done. 
Table 2

Construct Validity and Reliability

\begin{tabular}{|c|c|c|c|c|}
\hline Variable & Indicators & Loadings & Composite Reliability & AVE \\
\hline \multirow[t]{5}{*}{ GSCM } & GSCM1 & 0828 & 0.921 & 0.629 \\
\hline & GSCM2 & 0819 & & \\
\hline & GSCM3 & 0.666 & & \\
\hline & GSCM4 & 0.889 & & \\
\hline & GSCM5 & 0894 & & \\
\hline \multirow[t]{6}{*}{ EP } & EP1 & 0.666 & 0869 & 0.531 \\
\hline & EP2 & 0.927 & & \\
\hline & EP3 & 0.667 & & \\
\hline & EP4 & 0709 & & \\
\hline & EP5 & 0.690 & & \\
\hline & EP6 & 0.760 & & \\
\hline \multirow[t]{4}{*}{ GEP } & GEP1 & 0720 & 0873 & 0.633 \\
\hline & GEP2 & 0.783 & & \\
\hline & GEP3 & 0.853 & & \\
\hline & GEP4 & 0821 & & \\
\hline \multirow[t]{7}{*}{ GT } & GT1 & 0.925 & 0.921 & 0.629 \\
\hline & GT2 & 0841 & & \\
\hline & GT3 & 0.792 & & \\
\hline & GT4 & 0837 & & \\
\hline & GT5 & 0.620 & & \\
\hline & GT6 & 0742 & & \\
\hline & GT7 & 0.734 & & \\
\hline
\end{tabular}

In other words, this study has revealed that it fulfills convergent validity. Convergent validity can be checked through factor loading, reliability analysis, and composite reliability. Furthermore, the Average Variance Extracted (AVE) is also examined as one of the useful measures in building validity (Hair et al., 2017). Because by analyzing the convergent validity, it can ensure that the variables correlate well with each other in the parent factor, either the mediating variable or the dependent variable. Discriminatory validity is one of the steps to test the relationship of reflective variables with indicators. The measurement of discriminant validity based on the Fornell-Larcker postulate and cross-loading. Fornell-Larcker's postulate states that a latent variable shares more variants with the underlying indicator than with other latent variables. Statistically, the value of AVE for each latent variable must be greater than the highest R2 value with the value of the other latent variables. The second criterion for discriminant validity is "loading", for each indicator expected to be higher than "cross-loading" (Hair et al., 2017), as mentioned in Table 3.

Table 3

Discriminant Validity

\begin{tabular}{ccccc}
\hline Variable, b & 1 & 2 & 3 & 4 \\
\hline EP & 0728 & & & \\
GEP & 0.574 & 0.796 & & \\
GSCM & 0810 & 0.796 & 0.808 & 0.793 \\
GT & 0871 & 0.796 & 0.886 & 0.796 \\
\hline
\end{tabular}

Table 4

Predictive power of the construct

\begin{tabular}{cc}
\hline Construct & R2 \\
\hline EP & 0.785 \\
GEP & 0.625
\end{tabular}

As explained at the beginning of this section, after evaluating the reliability and validity of the instrument or simply saying after assessing the measurement of the conceptual model, the next step is to access the structured relationship between variables. The advantage of SEM-PLS over other statistical techniques is that it examines all structured relationships simultaneously (Chatchawanchanchanakij et al., 2019). Therefore, the direct and indirect effects are examined. Indirect effects are examined to check mediation in modeling structural equations. The bootstrapping procedure at 500 observations was adopted to determine the level of significance of the relationship proposed in this process. In data analysis, the relationship is said to be significant if the p-value is less than 0.05 (significance level of 5\%) and the t-value is above 1.96 . Immediate effect results, 
Table 5

Hypotheses testing

\begin{tabular}{cccccc}
\hline No & Hypotheses & $(\beta)$ & Elementary school & T Statistics & P Values \\
\hline$H 1$ & GSCM $\rightarrow$ EP & 0.445 & 0.195 & 2,278 & 0.023 \\
$H 2$ & GSCM $\rightarrow$ GEP & 0.467 & 0.147 & 3,180 & 0.002 \\
$H 3$ & Moderating Effect $1 \rightarrow$ EP & 0.407 & 0.181 & 2,248 & 0.025 \\
$H 4$ & Moderating Effect $1 \rightarrow$ GEP & -0.422 & $-0,397$ & 3,161 & 0.002 \\
\hline
\end{tabular}

Based on Table 5, GSCM Practices (GSCM) has a positive and significant effect on environmental performance (EP) with a p-value of 0.023 and a path coefficient of 0.445 . This coefficient indicates that better GSCM Practices (GSCM) will improve the performance environment (EP). The results of the hypothesis test indicate that H1 was accepted. Furthermore, GSCM Practices (GSCM) has a positive and significant effect on green economic performance (GEP) with p-value0.002 and the path coefficient of 0.467 . This coefficient shows that better GSCM Practices (GSCM) will improve green economic performance (GEP). The results of the hypothesis test show that H2 was accepted. Hypothesis testing of the moderating effect of Green technology (GT) can strengthen the positive relationship between GSCM Practices (GSCM) and environmental performance (EP) with a p-value of 0.025 and a path coefficient of 0.407 . This coefficient indicates that better green technology (GT) will further strengthen the positive relationship between GSCM Practices (GSCM) and environmental performance (EP). The result of the hypothesis test shows that H3 is accepted. The moderation effect of Green technology (GT) can weaken the positive relationship between GSCM Practices (GSCM) with green economic performance (GEP) with a p-value of 0.002 and the path coefficient of -0.422 . This coefficient shows a negative result, which means that more laborers practice Green technology (GT) will further weaken the positive relationship between GSCM Practices (GSCM) and environmental performance (EP). Based on the results of the hypothesis test shows that H4 is accepted.

\section{Discussion, Conclusion and recommendations}

\subsection{Conclusion}

The results of hypothesis testing indicate that GSCM practices (GSCM) have a positive and significant effect on environmental performance (EP). These results mean that better GSCM Practices (GSCM) can improve environmental performance (EP). The next test result is GSCM Practices (GSCM) has a positive and significant effect on green economic performance (GEP). These results indicate that the better Green technology (GT) will further strengthen the positive relationship between GSCM Practices (GSCM) and environmental performance (EP). We find that the role of green technology as a moderating variable can strengthen the positive relationship between GSCM Practices and environmental performance. The better the use and application of Green technology in the company will further enhance the company's environmental performance in the context of GSCM practice. While the moderation effect of Green technology (GT) can weaken the positive relationship between GSCM Practices (GSCM) and green economic performance (GEP). This shows that the more Green Technology (GT) practices, the weaker the positive relationship between GSCM Practices (GSCM) and environmental performance (EP) will weaken

\subsection{Discussion}

GSCM practices are designed and implemented to improve environmental sustainability (Fang \& Zhang, 2018). This statement corresponds with the results of our study, which shows that GSCM practices have a positive influence on environmental performance. Other literature also supports that GSCM practices can positively influence environmental performance (Zhu \& Sarkis, 2004).

H2 test results show that GSCM practices have a positive effect on green economic performance. Sustainable supplier collaboration has a positive influence on economic performance because alliances between organizations and companies in the supply chain can help to build trust and reduce risk. Furthermore, another reason that might explain the positive relationship between GSCM practices and economic performance is the effect of winning environmental awards on their share prices (Klassen \& McLaughlin, 1996). Specifically, Klassen and McLaughlin (1996) showed that the ecological behavior of companies is valued by the stock market, which rewards them with higher share prices. Recently, what has caught public attention is a form of business awareness on environmental issues through the adoption of GSCM with business innovation (Rao, 2007). The practice of green innovation was driven by technological progress (Ozturk et al., 2011). Before the environmental movement, researchers had recognized the important role of technology to facilitate the implementation of supply chain management (Legarth, 2001; Darnall et al. 2008). The general dimensions relate to objectives, processes, and support related to the possibility of business innovation, so the application of green technology can improve a company's environmental performance in the context of GSCM practices. However, the initial investment in technology is quite large, and it also requires a period for producers to get a return (Chan et al., 2912). The development and use of such technology can be a problem for companies because using technology requires expensive costs and requires massive investment (Allan et al., 2014). Besides, to continue to contribute to sustainable development, the energy sector 
must overcome the problem of ensuring an adequate energy supply and minimizing the environmental impacts associated with energy (Nguyen et al., 2019). At any given moment, the assumption that all companies whose benefits exceed costs adopt if the company has not done it before. This means that there will be a limit on the useful life, so that all companies whose benefits exceed this limit will adopt (or will have adopted before), and all companies whose benefits are below this level will not adopt. (Allan et al., 2014). Initially, costs are relatively high, but over time, the costs will go down. With each reduction in costs, more companies find interesting new technologies. Ameer and Othman (2012) empirically analyzed 100 sustainable global companies and found that the practice of an internal environment with a long-term orientation can lead to the return of assets, profits, and cash flow (Hollos et al., 2012). Regarding the practice of the external environment, it needs to be taken into account the level and time of return as well as the costs \& benefits of the long-term investment. Some environmentally friendly technologies impose new capital costs and increased operational costs on their users, so the adoption of green technology occurs only because of the result from the reduction of desired or necessary externalities (Allan et al., 2016). In other cases, pollution reduction is associated with the use of more efficient materials and/or energy inputs, so operating costs are reduced along with it. Therefore, some public research and advocacy claims that costefficiency must be obtained through the wider adoption of existing technologies that will reduce environmental impacts and save money for adopters (McKinsey, 2009)

\subsection{Recommendation}

The results of our study provide more encouragement for managers who take GSCM practices to help improve many aspects of company performance (environment and green economic performance). Due to the adoption of GSCM practices over the years, positive results may have already occurred, further strengthening their confidence in implementing these environmental initiatives. Second, our finding is about the role of GSCM's green technology in the aspect of company performance. Green technology can be adopted by companies for GSCM practices in improving environmental performance, or to attract investors who care about the environment and to get awards. For example, in Indonesia: The Ministry of Environment-Indonesia provides "PROPER" awards for companies that are concerned with the environment on several levels. Third, the results of our study provide recommendations for managers to consider the costs $\&$ benefits of adopting green technology. Because some green technology imposes new capital costs and increased operational costs on its users, adoption of green technology occurs only because the reduction resulting from externalities is desirable or necessary. This study has a limitation: the writers do not analyze data based on industry type and company size. Therefore, future research can be developed by including the type of industry and company size as a control variable in GSCM practices.

\section{Acknowledgment}

The authors thank LPDP (Educational Fund Management Agency), Ministry of Finance of the Republic of Indonesia for financial support in writing this article.

\section{Refferences}

Allan, C., Jaffe, A. B., \& Sin, I. (2013). Diffusion of green technology: A survey. International Review of Environmental and Resource Economics, 7(1), 1-33. https://doi.org/10.1561/101.00000055

Ba, S., Lisic, L. L., Liu, Q., \& Stallaert, J. (2013). Stock market reaction to green vehicle innovation. Production and Operations Management, 22(4), 976-990. https://doi.org/10.1111/j.1937-5956.2012.01387.x

Bhattacharya, A., Mohapatra, P., Kumar, V., Dey, P. K., Brady, M., Tiwari, M. K., \& Nudurupati, S. S. (2014). Green supply chain performance measurement using fuzzy ANP-based balanced scorecard: A collaborative decision-making approach. Production Planning and Control, 25(8), 698-714. https://doi.org/10.1080/09537287.2013.798088

Çankaya, S. Y., \& Sezen, B. (2019). Effects of green supply chain management practices on sustainability performance. Journal of Manufacturing Technology Management, 30(1), 98-121.

Chan, R. Y., He, H., Chan, H. K., \& Wang, W. Y. (2012). Environmental orientation and corporate performance: The mediation mechanism of green supply chain management and moderating effect of competitive intensity. Industrial Marketing Management, 41(4), 621-630.

Chatchawanchanchanakij, P., Arpornpisal, C., \& Jermsittiparsert, K. (2019). The role of corporate governance in creating a capable supply chain: A case of Indonesian Tin industry. International Journal of Supply Chain Management, 8(3), 855-864.

Cousins, P. D., Lawson, B., Petersen, K. J., \& Fugate, B. (2019). Investigating green supply chain management practices and performance: The moderating roles of supply chain ecocentricity and traceability. International Journal of Operations and Production Management, 39(5), 767-786. https://doi.org/10.1108/IJOPM-11-2018-0676

Doran, J., \& Ryan, G. (2014). Eco-Innovation-does additional engagement lead to additional rewards?. International Journal of Social Economics, 41(11), 1110-1130.

Frohlich, M.T., \& Westbrook, R. (2002). Arcs of integration: an international study of supply chainstrategies. Journal of Operations Management, 19(2), 185-200.

Gavronski, I., Klassen, R. D., Vachon, S., \& Nascimento, L. F. M. do. (2011). A resource-based view of green supply management. Transportation Research Part E: Logistics and Transportation Review, 47(6), 872-885. 
https://doi.org/10.1016/j.tre.2011.05.018

Gimenez, C., \& Ventura, E. (2005). Logistics-production, logistics-marketing and external integration. International Journal of Operations \& Production Management, 25(1), 20-38.

Green, K. W., Zelbst, P. J., Meacham, J., \& Bhadauria, V. S. (2012). Green supply chain management practices: Impact on performance. Supply Chain Management, 17(3), 290-305. https://doi.org/10.1108/13598541211227126

Hair, J.F. Jr, Hult, G.T.M., Ringle, C. and Sarstedt, M. (2016), A Primer on Partial Least Squares Structural Equation Modeling (PLS-SEM), Sage Publications, Thousand Oaks, CA.

Hart, S. L., \& Dowell, G. (2011). Invited editorial: A natural-resource-based view of the firm: Fifteen years after. Journal of Management, 37(5), 1464-1479.

Holt, D., \& Ghobadian, A. (2009). An empirical study of green supply chain management practices amongst UK manufacturers. Journal of Manufacturing Technology Management, 20(7).

Heinkel, R., Kraus, A., \& Zechner, J. (2015). The Effect of Green Investment on Corporate Behavior Author ( s ): Robert Heinkel, Alan Kraus and Josef Zechner Source: The Journal of Financial and Quantitative Analysis, Vol . 36 , No . 4 ( Dec ., 2001 ), pp . Business Administration. Journal of Financial and Quantitative Analysis, 36(4), 431-449.

Horbach, J., Rammer, C., \& Rennings, K. (2012). Determinants of eco-innovations by type of environmental impact-The role of regulatory push/pull, technology push and market pull. Ecological Economics, 78, 112-122.

Jaaron, A. A., Zaid, A. A., \& Bon, A. T. (2018, June). The impact on organizational performance of linking green supply chain management with supply-chain integration: a conceptual model. In Proceedings of the 25th Annual EurOMA International Conference (Vol. 24, p. 26).

Kemp, R., \& Oltra, V. (2011). Research insights and challenges on eco-innovation dynamics. Industry and Innovation, 18(03), 249-253.

Knobloch, F., \& Mercure, J. F. (2016). The behavioural aspect of green technology investments: A general positive model in the context of heterogeneous agents. Environmental Innovation and Societal Transitions, 21, 39-55. https://doi.org/10.1016/j.eist.2016.03.002

Laosirihongthong, T., Adebanjo, D., \& Choon Tan, K. (2013). Green supply chain management practices and performance. Industrial Management \& Data Systems, 113(8), 1088-1109. https://doi.org/10.1108/IMDS-04-2013-0164

Larson, E. W., \& Gray, C. F. (2006). Project Management: The Managerial Process (Special Indian Edition). Tata McGraw-Hill Education.

MacKenzie, S. B., \& Podsakoff, P. M. (2012). Common method bias in marketing: Causes, mechanisms, and procedural remedies. Journal of Retailing, 88(4), 542-555.

Mehdikhani, R., \& Valmohammadi, C. (2019). Strategic collaboration and sustainable supply chain management. Journal of Enterprise Information Management, 32(5), 778-806.

Patidar, R., \& Din, T. M. U. (2018). A Study on the Fluctuating Trend of Export (Demand Change) of 'Garlic of India'by its Price Transformation in International Markets, Under the Time Period of 1991 to 2011. International Journal of Applied Economics, Finance and Accounting, 2(2), 54-59.

Pono, M., \& Munizu, M. (2021). Uncertain Supply Chain Management The role of company competitiveness as mediation variable the impact of supply chain practices on operational performance. 9. https://doi.org/10.5267/j.uscm.2020.11.002

Rao, P. (2007). Greening of the supply chain: An empirical study for SMES in the Philippine context. Journal of Asia Business Studies, 1(2), 55-66.

Rennings, K., \& Rammer, C. (2011). The impact of regulation-driven environmental innovation on innovation success and firm performance. Industry and Innovation, 18(03), 255-283.

Saeed, A., Jun, Y., Nubuor, S. A., Priyankara, H. P. R., \& Jayasuriya, M. P. F. (2018). Institutional pressures, green supply chain management practices on environmental and economic performance: A two theory view. Sustainability, 10(5), 1517.

Susanty, A., Sari, D. P., Rinawati, D. I., \& Setiawan, L. (2019). The role of internal and external drivers for successful implementation of GSCM practices. Journal of Manufacturing Technology Management, 30(2), 391-420. https://doi.org/10.1108/JMTM-07-2018-0217

Wikaningrum, T., \& Hakiki, R. (2020). Key performance indicators (KPIs) comparison of food chain reactor and conventional oxidation ditch technology in industrial waste treatment. Journal of Environmental Engineering and Waste Management, 5(1), 15-29.

Zhu, Q., \& Sarkis, J. (2007). The moderating effects of institutional pressures on emergent green supply chain practices and performance. International Journal of Production Research, 45(18/19), 4333-4355.

Zhu, Q., Geng, Y., \& Sarkis, J. (2013). Motivating green public procurement in China: An individual level perspective. Journal of Environmental Management, 126(August 2015), 85-95. https://doi.org/10.1016/j.jenvman.2013.04.009

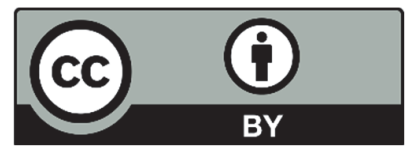

(C) 2021 by the authors; licensee Growing Science, Canada. This is an open access article distributed under the terms and conditions of the Creative Commons Attribution (CC-BY) license (http://creativecommons.org/licenses/by/4.0/). 